УДК 658.012.08:338.47

\title{
ЗАСТОСУВАННЯ ПРОАКТИВНОГО ПІДХОДУ ПРИ ФОРМУВАННІ ЕКОНОМІЧНОЇ БЕЗПЕКИ НА ЗАЛІЗНИЧНОМУ ТРАНСПОРТІ
}

Зайцева I.Ю., д.е.н., професор,

Ковтун Т.В., аспірант (УкрДУЗТ)

\begin{abstract}
Стаття присвячена висвітленню реактивного та проактивного аспектів в управлінні підприємством, порівнянню особливостей реалізації даних методів, виділенню суттєвих переваг проактивного методу управління та несуттєвих недоліків у порівнянні з реактивним методом, аналізу існуючих підходів до визначення економічної безпеки, щзо характеризують певні аспекти захищеності підприємства, введенню та адаптації проактивного підходу при формуванні $і$ забезпеченні економічної безпеки підприсмства залізничного транспорту.
\end{abstract}

Ключові слова: реактивний метод, проактивний метод, проактивне управління діяльністю підприсмства залізничного транспорту, економічна безпека підприємства залізничного транспорту.

\section{ПРИМЕНЕНИЕ ПРОАКТИВНОГО ПОДХОДА ПРИ ФОРМИРОВАНИИ ЭКОНОМИЧЕСКОЙ БЕЗОПАСНОСТИ НА ЖЕЛЕЗНОДОРОЖНОМ TРАНСПОРТЕ}

\author{
Зайцева И.Ю., д.э.н., профессор, \\ Ковтун T.В., аспирант (УкрГУЖТ)
}

\begin{abstract}
Статья посвящена описанию реактивного и проактивного аспектов в управлении предприятием, сравнению особенностей реализации данных методов, выделению существенных преимуществ проактивного метода управления и несущественных недостатков по сравнению с реактивным методом. В статье проанализировано существующче подходы $к$ определению экономической безопасности, характеризуюшие определенные аспекты защчищенности предприятии. Введено и адаптировано проактивный подход при формировании и обеспечении экономической безопасности предприятия железнодорожного транспорта.
\end{abstract}

Ключевые слова: реактивный метод, проактивный метод, проактивное управление деятельностью предприятия железнодорожного транспорта, экономическая безопасность предприятия железнодорожного транспорта.

\section{APPLYING OF A PROACTIVE A PPROACH AT THE PROCESS OF FORMING OF ECONOMIC SECURITY ON RAILWAY TRANSPORT}

\author{
Zayceva I.Yu, Doctor of Economic Sciences, professor, \\ Kovtun T.V., postgraduate (USU of RT)
}

In the article it is determined that there are reactive and proactive methods in enterprises management. The features of implementation these methods and their advantages and disadvantages were considered. Essential advantages of proactive management method and minor flaws compared to reactive method were determined. The proactive approach is used in crisis management and risk management, in marketing management and quality management, at information technology and programming, in ecological projects management and other areas. Existing approaches to the wording economic security of enterprise were analyzed. In modern economic climate it becomes necessary the introduction of a proactive approach to the definition economic security of enterprise of railway transport. It was determined that proactive management of enterprises of railway transport it is a process based on the warning management activities, taking into account of negative results of its activity. It was determined that proactive management of enterprises of railway transport it is a process based on the warning managerial actions, taking into account of negative results of its activity. Application of proactive management of economic security has essential advantages in protecting enterprise of railway transport. Also the proactive approach must be applied in ensure and management of financial security as a component of economic security at railway transport.

Keywords: reactive method, proactive method, proactive management of enterprise's activity of railway transport, economic security of enterprise of railway transport.

(c) Зайцева I.Ю.,

Ковтун Т.В.
Вісник економіки транспорту і промисловості № 50, 2015 
Постановка проблеми. Актуальність. Відповідно до змін умов зовнішнього середовища у процесі дослідження таких понять як економічна безпека змінювалися i підходи щодо їx формулювання та формування. У процесі перетворень в операційному середовищі підприємств економічна безпека характеризували особливі сторони захисту відповідно до викликів певного часу. На жаль, сучасне економічне, політичне, соціальне середовище характеризується нестабільністю, виникненням нових форм викликів та загроз. Особливої уваги щодо створення безпеки потребують підприємства залізничної галузі, що перебуває на стадії реформування. Виникає необхідність у удосконаленні існуючих підходів до визначення i побудови економічної безпеки на залізничному транспорті.

Аналіз останніх досліджень і публікацій. Питання застосування проактивного підходу та проактивного управління підприємством в різних сферах економічного характеру, впровадженню інноваційних методик проактивного управління висвітлено у працях таких авторів: Н.М. Гуржій [1], О.О. Плахотнік [2], I.М. Суворова [3], Н.О. Держак [4], Г.О. Чорноус [5] та інші. Формуванням і забезпеченням екомічної безпеки присвячені праці таких науковців С.А. Олейніков [6], В.Л. Дикань, І.Л. Назаренко [7], Васильців Т.Г. [8], Прохорова В.В., Прохорова Ю.В., Кучеренко O.O. [9], В.І. Франчук [10] та інших. Ці питання стосовно залізничного транспорту висвітлені у працях Р.А. Кожевникова [11], Костюк Ж.С. [12] та інших.

Виділення невирішених частин загальної проблеми. Проактивний механізм застосовується у таких сферах як антикризове управління та ризикменеджменті, в маркетинговому управлінні, управлінні якістю, в інформаційних технологіях та програмуванні, в управлінні екологічними проектами, в управлінні автотранспортними підприємствами та інших. Але, нажаль, в управлінні економічною безпекою проактивний підхід не застосовується. Тому є необхідність у введені і адаптації даного підходу на залізничному транспорті.

Метою статті $є$ застосування проактивного підходу до формування і забезпечення економічної безпеки на залізничному транспорті.

Виклад основного матеріалу. Традиційними для вітчизняної управлінської практики методологічними підходами $\epsilon$ функціонально орієнтовані, зазвичай, вони використовуються в процесі формування механізму реактивного управління змінами. Реактивні підприємства проявляють свою активність як реакцію на ті або інші явища зовнішнього і внутрішнього характеру (діï), але що не прогнозує зміни i що не впливає на них.
Реактивне управління можна визначити як дії підприємства у вигляді негайних реакцій на зміни, що відбуваються на ринку. Ці дії характеризуються наступним: мають оперативний характер i направлені на корегування стратегії і тактики; достатньо швидкі, але можуть носити накопичувальний характер, що, у результаті, може змінити загальну поведінку підприємства на ринку; негайні в режимі реального часу.

Такі дії, насправді, не передбачають прогнозу результату, не здатні впливати на зміну внутрішнього та зовнішнього середовища підприємства та робить зовсім незахищеними перед новими викликами та загрозами. Реалізація реактивного управління вимагає швидких дій за короткий проміжок часу, значних фінансових затрат, необхідність у високопрофесійних спеціалістах, а саме брак у цих ресурсах і виникає при кризових ситуаціях. Натомість, проактивний підхід дозволить заздалегідь бути готовим до процесів, що викликають нестабільність та незбалансованість діяльності. Розглянемо наглядно переваги та недоліки даних методів (рис. 1).

Для визначення економічної безпеки підприємства залізничного транспорту, враховуючі особливості проактивного управління, розглянемо існуючі підходи. У науковій літературі пропонуються такі підходи до формулювання поняття економічної безпеки підприємства:

1) силовий підхід, захист комерційної таємниці (Раздіна Є.В. [16]);

2) підхід стабільності(Камлик М.I. [17], Варналія 3.С. [18]);

3) математичний підхід (Забродський В. [19]);

4) підхід захисту, реалізації інтересів, в т.ч. економічних (Іванов А.В., Шликов В.В. [20], Раздіна Є.В. [16], Франчук В.I. [10]);

5) ресурсно-функціональний підхід, як стан ефективного використання ресурсів, потенціалу та виділення функціональних складових (Олейніков Є.А. [6], Гетьман О.О., Шаповал В.М. [21], Варналія 3.С. [18], Дикань В.Л., Назаренко І.Л. [7]);

6) стратегічний підхід, 3 точки зору захисту від внутрішніх і зовнішніх загроз (Козаченко Г.В., Пономарьов Р.П., Ляшенко О.М. [22], Прохорова В.В., Прохорова Ю.В., Кучеренко O.O. [9], Гетьман О.О., Шаповал В.М. [21], Іванілов О.С. [23], Дикань В.Л., Назаренко І.Л. [7]);

7) кримінальний підхід; як захист від корисливих, економічних злочинів (Мочерний С.В. [24]);

8) гармонізаційний підхід, гармонізація економічних інтересів (Зайцева I.Ю. [25], Мочерний С.В. [24]);

9) ринковий підхід, наявність конкурентних переваг (Кашин А.В. [26]). 


\begin{tabular}{|c|c|c|}
\hline Проактивний підхід & & Реактивний підхід \\
\hline $\begin{array}{l}\text { - орієнтоване в основному на } \\
\text { майбутнє, на здійснення безпе- } \\
\text { рервних змін в різних напрямах } \\
\text { діяльності підприємства; } \\
\text { - прогнозуються ймовірні } \\
\text { напрями змін, щоб скоріше } \\
\text { досягти своєї мети; } \\
\text { - спрямоване на пошук } \\
\text { оптимального рішення, вибір } \\
\text { альтернатив розвитку; } \\
\text { - прагнення врахувати як фактори } \\
\text { внутрішнього, так зовнішнього } \\
\text { середовища та їх зміни; } \\
\text { - наявність контролю над часом } \\
\text { для вирішення проблеми; } \\
\text { - є можливість детальніше } \\
\text { розглянути і вивчити процеси, що } \\
\text { впливають на діяльність } \\
\text { підприємства, краще оцінити, } \\
\text { проаналізувати та передбачити } \\
\text { можливі ризики та загрози; } \\
\text { - ретельний підхід до } \\
\text { формулювання стратегіі } \\
\text { підприємства та головних цілей } \\
\text { його діяльності як цілісної } \\
\text { програми їх досягнення, тобто } \\
\text { дотримання принципу } \\
\text { синергетизму. } \\
\text { - дотримання принципу } \\
\text { партисипативності; } \\
\text { - використання останніх досяг- } \\
\text { нень науки та техніки, новітніх та } \\
\text { прогресивних методів управління, } \\
\text { планування та прогнозування; } \\
\text { - мета проактивного планування - } \\
\text { виживання та зростання } \\
\text { підприємства. } \\
\text { - не вимагає від робітників } \\
\text { швидкого переходу від виконання }\end{array}$ & 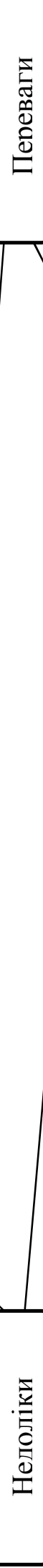 & 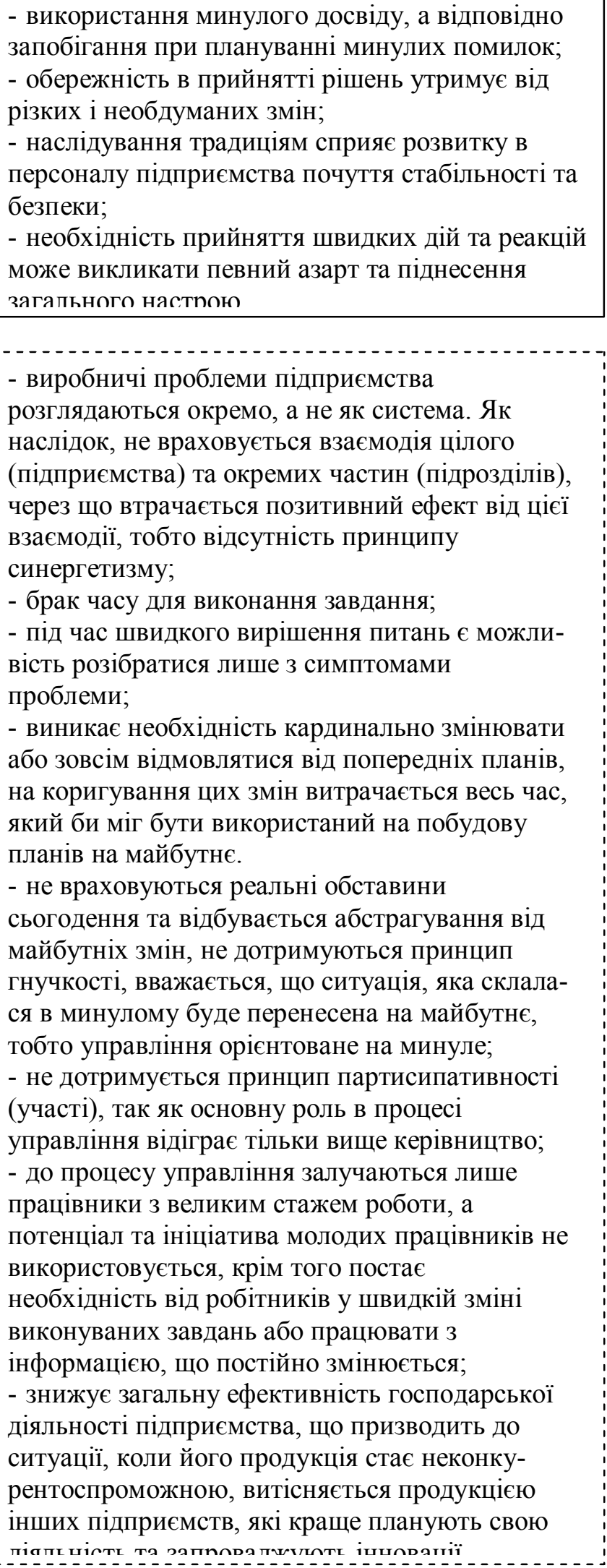 \\
\hline
\end{tabular}

Рис. 1. Переваги та недоліки реактивного та проактивного підходів (складено на основі джерел 13, 14, 15)

Вісник економіки транспорту і промисловості № 50, 2015 
Найбільш поширеним та застосовуваним є ресурсно-функціональний та стратегічний підходи, в тому числі і на залізничному транспорті, але вони потребують удосконалення. Дані підходи частково враховують принципи проактивності, але поза увагою залишаються важливі моменти які необхідно врахувати при управлінні економічною безпекою. Тому, у сучасних умовах господарювання постає необхідність у виділенні нового наукового підходу до визначення економічної безпеки підприємства залізничного транспорту 3 точки зору його проактивного управління. Особливої важливості цей підхід набуває в умовах реформування залізничного транспорту в Україні. Підприємства 3 проактивною поведінкою прогнозують (в результаті спостережень, вимірювань, аналізу) можливі дії і впливають на них і на себе, попереджуючи їх. Зазначений підхід полягає в тому, щоб постійно вивчати змінні межі можливого і в цих рамках досягати поставлених цілей, зокрема цілей зростання і розвитку.

На наш погляд, проактивне управління діяльністю підприємства залізничного транспорту - це процес, заснований на попереджуючих управлінських діях, що враховують можливість виникнення негативних результатів його діяльності. Використовуючи проактивне управління, підприємства залізничного транспорту розробляють свій власний курс ринкового руху і діють у вибраному напрямі. Проактивне підприємство здатне вивчати себе, навколишнє середовище i змінюватися, використовуючи ці знання, щоб забезпечити попереджуючий розвиток по відношенню до динаміки потреб споживачів і викликів конкурентів у середині галузі та за ii межами на основі балансу інтересів зацікавлених сторін. Таким чином, підприємство використовує проактивну модель ухвалення управлінських рішень.

Таким чином, проаналізувавши існуючі підходи до визначення економічної безпеки та враховуючи суттєві переваги проактивного підходу, визначаємо економічну безпеку підприємства залізничного транспорту як комплексне поняття, що характеризує захищеність підприємства від внутрішніх та зовнішніх загроз шляхом проактивного управління ним, використовуючи наявний потенціал та можливості для досягнення стратегічних інтересів та головної мети його функціонування та розвитку.

Висновки. Отже, застосування проактивного підходу у формуванні та управлінні економічною безпекою на залізничному транспорті дасть можливість передбачити ризики та загрози внутрішнього та зовнішнього середовища, підготуватися до попередження проблем, виділити пріоритетні і найбільш важливі задачі, врахувати необхідні для цього ресурси та ефективно їх використовувати, змінити план після початку роботи, додати нові задачі, отримати додатковий час для аналізу поточних дій для покращення якості їх виконання, a також для планування розв'язання проблем.

Ефективність діяльності підприємств залізничного транспорту у ринковій економіці обумовлюється багато в чому станом його фінансів, особливо в умовах реформування. Постає необхідність розгляду питання забезпечення фінансової безпеки підприємства залізничного транспорту, як складової економічної безпеки. Подальшим напрямком дослідження є введення та адаптація проаткивного підходу при забезпеченні фінансової безпеки на залізничному транспорті та управлінні їі рівнем.

\section{СПИСОК ЛІТЕРАТУРИ}

1. Гуржій Н.M. Механізм проактивного управління стратегічною маркетинговою стійкістю / Н.М. Гуржій. - Вісник ОНУ імені I.І.Мечникова. - 2013. - Т.18.- Випуск 2. - С. 110-119.

2. Плахотнік О.О. Ефективні механізми проактивного антикризового управління підприємствами: автореф. дис. ... канд. екон. наук: 08.00.04 / Державний вищий навчальний заклад «Приазовський державний технічний університет» / О.О. Плахотнік. - Маріуполь, 2011. - 22 с.

3. Суворова I.M. Проблеми оцінювання фінансового стану авіатранспортних підприємств України для забезпечення ефективного процесу проактивного управління / I.M. Суворова. Глобальні та національні проблеми економіки. Миколаїв: МНУ імені В. О. Сухомлинського, 2014. - Випуск 2. - С. 720-724.

4. Держак Н. О. Управління реакціями підприємства на ринкові зміни / Н.О. Держак. Маркетинг i менеджмент інновацій. - Суми : Видавництво СумДУ, 2011. - №3. -Т. 1. - С. 98102.

5. Чорноус Г.О. Інформаційна підтримка проактивного управління підприємством / Г.О. Чорноус. - Теоретичні та прикладні питання економіки: збірник наукових праць. - К: Видавничо-поліграфічний центр «Київський університет», 2011. - Випуск 26. - С. 88-95.

6. Основы экономической безопасности: (государство, регион, предприятие, личность): Учеб.-практ. Пособие / Под ред. Олейникова Е.А. М.: ЗАО «Бизнес-школа «Интел-Синтез», 1997. $279 \mathrm{c}$.

7. Дикань В.Л. Комплексна методика визначення рівня економічної безпеки, оцінки ризиків та ймовірності банкрутства підприємства: Монографія / В.Л. Дикань, І.Л. Назаренко; Українська державна академія залізничного транспорту. - Х.: УкрДАЗТ, 2011. - 142 с.

8. Васильців Т.Г. Економічна безпека

Вісник економіки транспорту і промисловості № 50, 2015 
підприємництва України: стратегія та механізм зміцнення: Монографія. / Т.Г. Васильців - Львів: Арал, 2008. - 384 с.

\section{9. Прохорова}

В.В. Управління економічною безпекою підприємств: [Монографія] / В.В. Прохорова, Ю.В. Прохорова, О.О. Кучеренко; [Українська державна академія залізничного транспорту]. - Х.: УкрДАЗТ, 2010. - 283 с.

10. Франчук В.І. Основи економічної безпеки: навч. посіб. / В.І. Франчук. - Львів. держ. ун-т внугр. справ. - Львів: Каменяр, 2009. - 203 с.

11. Кожевников Р.А. Экономическая безопасность железнодорожного трансопрта: Учебник для вузов ж.-д. транспорта / Р.А. Кожевников, 3.П. Межох, Н.П. Терешина и др. М.: Маршрут, 2005. - 326 c.

12. Костюк Ж.С. Сутність поняття «Економічна безпека підприємств залізничного транспорту» / Ж.С. Костюк // Вісник економіки транспорту і промисловості. - 2013. - №41. - С. 173-179.

13. Планування діяльності підприємства [Електронний ресурс]. - Режим доступу: http://labook.com.ua/book_planuvannya-diyalnostipidpriyemstva_849/6_nedoliki-reaktivnogoplanuvannya. - Назва з екрану.

14. Стратегічне планування як головна умова функціонування підприємства [Електронний ресурс]. http://pidruchniki.com/13820328/menedzhment/strateg ichne_planuvannya_golovna_umova_funktsionuvanny a_pidpriyemstva. - Назва з екрану.

15. From Reactive to Proactive Management [Electronic Resource]. - Mode of access: http://www.mindtools.com/pages/article/reactiveproactive-management.htm. - Title from the screen.

16. Раздина Е.В. Экономическая безопасность: сущность и тенденции развития: Автореферат дис. ... канд. экон. наук: 08.00.01.
МГУ им. М.В. Ломоносова./ Е.В. Раздина - М., 1998. -22 c.

17. Камлик M.I. Економічна безпека підприємницької діяльності. Економіко-правовий аспект: Навч. посіб. / M.I. Камлик - К.: Атіка, 2005. $-431 \mathrm{c}$.

18. Економічна безпека: навч. посіб. / за ред. 3.С. Варналія. - К.: Знання, 2009. - 647 с.

19. Забродский В. Теоретические основы экономической безопасности отрасли и фирмы / В. Забродский, Н. Капустин // Бизнес-информ. 1999. - № 13. - С. 35-37.

20. Иванов А.В. Экономическая безопасность предприятий / А.В. Иванов, В.В. Шлыков - М.: Вираж-Центр, 1995. - 40 с.

21. Гетьман О.О. Економічна діагностика: Навч. посіб. для студентів ВНЗ / О.О. Гетьман, B.M. Шаповал - Київ: Центр навчальної літератури, 2007. - 307 с.

22. Козаченко Г.В. Економічна безпека підприємства: сутність та механізм забезпечення: Монографія / Г.В. Козаченко, Р.П. Пономарьов, О.М. Ляшенко - К.: Лібра, 2003. - 280 с.

23. Іванілов О. С. Економіка підприємства: підруч. [для студ. вищ. навч. закл.] / О. С. Іванілов - К.: Центр учбової літератури, 2009. - 728 с.

24. Економічна енциклопедія: У трьох томах / Редкол.: С.В. Мочерний (відп. ред.) та ін.. К.: Видавничий центр «Академія», 2000. - 864 с. T. 1.

25. Зайцева I.Ю. Економіко-організаційні основи захисту підприємств автотранспорту від недружніх поглинань: Монографія / І.Ю. Зайцева Харків: УкрДАЗТ, 2011. - 427 с.

26. Кашин А.В. Экономическая безопасность предприятия: управленческие проблемы / А.В. Кашин // Экономика управления. - 2008. - №1.- C. 11-12.

Експерт редакційної колегії к.е.н., доцент УкрДУЗТ Назаренко І.Л.

УДК 305.81: 602

\title{
МОДЕЛЬ ЕКОНОМІКИ ТА УПРАВЛІННЯ ГОСПОДАРСТВОМ ПАСАЖИРСЬКИХ ПЕРЕВЕЗЕНЬ ЗАЛІЗНИЧНОГО ТРАНСПОРТУ
}

\author{
Котик В.О., к.е.н., доцент, \\ Котик В.В., к.е.н., доцент (УкрДУЗТ)
}

Збитковість пасажирських перевезень залізничного транспорту з кожним роком збільшується в наслідок як об'єктивних так і суб'єктивних причин. У зв'язку з ичим в статті авторами виконано огляд праць вітчизняних $i$ зарубіжних вчених по досліджуваній проблемі. Обгрунтовано теоретичні, методологічні та методичні підходи і конщептуальні засади щзодо вдосконалення діючої системи управління збиткових пасажирських перевезень залізничного транспорту та поступового вирішення питань їх фінансування за рахунок механізмів державного втручання.

(C) Котик B.O.,

Котик В.В.
Вісник економіки транспорту і промисловості № 50, 2015 